\title{
Limitations of the Elderly: Current Situation and Importance of Formal Activities
}

\author{
Ma Sagrario Gómez Cantarino ${ }^{1 *}$, Minerva Velasco Abellán² and Blanca Espina Jerez ${ }^{3}$ \\ ${ }^{1}$ Department of Nursing, Physiotherapy \& Occupational Therapy, University of Castilla-La Mancha, Spain \\ ${ }^{2}$ Clinical Psychologist and Health, Student of Bachelor Degree in Nursing,spain
}

${ }^{3}$ Professor Associated Clinic, School of Nursing and Physiotherapy, University of Castilla-La Mancha \& Hospital complex of Toledo, Collaborator Endocu research group, spain

Submission: May 03, 2018; Published: May 11, 2018

*Corresponding author: Sagrario Gómez Cantarino, Department of Nursing, Physiotherapy and Occupational Therapy, Tel: +35925268800; Email: sagrario.gomez@uclm.es

\section{Opinion}

Spain is one of the countries that ages at a faster rate. This phenomenon is due to three trends:
a) Fall in fertility
b) High life expectancy
c) High immigration [1].

The three factors have created a demographic framework that affects the composition and formation of families, the educational system, the housing market and the health needs of the population, not only in their quantity, but also in the type of pathologies to be considered [2]. As the population ages, the importance of the behaviors and repercussions associated with older age groups increases, such as the situation of pensions, taxes and financing of the Social Security, ultimately the entire Welfare State [3].With regard to the health and care needs of the elderly, there are two types of care, family and formal. The field of nursing specialized in the care of the elderly is Geriatrics [4]. Its purpose is to help the elderly and their caregivers to face the aging process, understanding it as a natural and adaptive process and intervening in maximizing their sources of power. According to Balboa [5], these are: physical strength, psychological and social reserve, self-concept and self-esteem, energy, motivation and beliefs. In order to empower and maintain them, it is necessary the participation of nursing professionals who stand out for their attitudes, skills and values in the field of ethics, humanitarian attitude, sensitivity, respect and affection for the elderly, as well as the interest of development and continuous professional training. Dependence in elderly people in Spain has become a serious problem both socially and healthily. According to the National Institute of Statistics [6] it is estimated that the ratio of dependents in 2066 in Spain will correspond to 34.6\% of the population. This situation has caused that people without acute pathologies have been displaced from hospital care when the hospital has been crowded by the aging population.
Currently, public health centers are very scarce, so the lack of coverage leads to the displacement of the elderly person from the hospital to the home, instead of recovering or achieving optimal maintenance through follow-up in the Day Centers or Residences. On the other hand, institutionalization is culturally associated with a lack of affection and responsibility of the family with the eldest, in addition to the fact that older people generally want to live in their homes [7]. However, when the care of the elderly is in the hands of nursing, professionals must apply their knowledge and skills, without forgetting the construction of the human nurse and client relationship, in order to ensure the improvement or cure of the disease, the relief of suffering, or in the last case, the accompaniment in the process of death. Nursing supplies the client when he can no longer take charge of self-care, and they encourages and reinforces when he can take care of himself, but does not have the strength, will or knowledge needed. In addition, nursing seeks to guarantee the physical and psychological intimacy of the elderly patient. The adaptation, acceptance and positive construction of aging are not easy tasks for older adults, and these requires the nursing professional to promote values such as respect for others, autonomy and compassion, to provide humanized care to the older adult and to teach his direct group of caregivers to optimize the relative care. The elderly client capable of exercising their autonomy should be responsible for their own decisión making that the nursing professional must respect according to their legal and human rights.

\section{References}

1. López V (2011) White paper on active aging. ( $\left.1^{\text {st }} e d n\right)$, Madrid: Ministry of Health Social Policy and Equality General Secretariat of Social Policy and Consumption, Institute for the Elderly and Social Services (IMSERSO).

2. Bryant J, Teasdale A, Cheung J, Mchugh M (2004) Population ageing and government health expenditures in New Zealand, 1951-2051.

3. Guijarro, M y Peláez O (2008) The globalized longevity: an analysis of life expectancy in Spain (1900-2050). Scripta Nova 12(260). 
4. Gómez S, Duque C, Sukkarieh S (2015) Multidisciplinary training in specialized health training: other multiprofessional units in specialized health training from the point of view of nursing.

5. Balboa M, Pérez M, Sarasola JL (2012) Healthy proposals for active aging. Hekademos Education Magazine 11(5): 2936.

This work is licensed under Creative

Commons Attribution 4.0 License
6. National Institute of Statistics (2016) Population projections 20162066.

7. (2010) Institute of Seniors and Social Services (IMSERSO) Survey of the active population.

\section{Your next submission with Juniper Publishers will reach you the below assets}

- Quality Editorial service

- Swift Peer Review

- Reprints availability

- E-prints Service

- Manuscript Podcast for convenient understanding

- Global attainment for your research

- Manuscript accessibility in different formats

( Pdf, E-pub, Full Text, Audio)

- Unceasing customer service

Track the below URL for one-step submission https://juniperpublishers.com/online-submission.php 